\title{
Docudramatizing the real: developments in British TV docudrama since 1990
}

Article

Accepted Version

Bignell, J. (2011) Docudramatizing the real: developments in British TV docudrama since 1990. Studies in Documentary Film, 4 (3). pp. 195-208. ISSN 1750-3280 doi: https://doi.org/10.1386/sdf.4.3.195_1 Available at https://centaur.reading.ac.uk/19486/

It is advisable to refer to the publisher's version if you intend to cite from the work. See Guidance on citing.

To link to this article DOI: http://dx.doi.org/10.1386/sdf.4.3.195_1

Publisher: Intellect

Publisher statement: (OIntellect 2011

All outputs in CentAUR are protected by Intellectual Property Rights law, including copyright law. Copyright and IPR is retained by the creators or other copyright holders. Terms and conditions for use of this material are defined in the End User Agreement.

\section{www.reading.ac.uk/centaur}

\section{CentAUR}

Central Archive at the University of Reading

Reading's research outputs online 


\title{
Docudramatizing the real: Developments in British TV docudrama since 1990
}

Jonathan Bignell University of Reading

\begin{abstract}
The article discusses the reasons for the growth in television docudrama in Britain since 1990. These stimulating factors include regulatory frameworks, especially the Broadcasting Act of 1990 that affected existing television institutions by introducing increased competition and budgetary pressures. Challenges to television documentary from falling audiences, and to drama from rising costs, also led to a reconfiguration of British television schedules and the emergence of new hybrid programme genres. The pressures of this changed environment led the hybrid form of docudrama to take on some of the functions of history programmes, social affairs, political investigation and responses to key events such as the September 11, 2001attacks. Docudrama makers were increasingly required to seek co-production finance and distribution deals with overseas television channels. Docudrama was already controversial because of its relationship with antecedent documentary and dramatic traditions, but the post-1990 British contexts presented both new problems and new opportunities. The relative immediacy of docudrama and its engagement with public affairs, married with its performativity and personalized mode of address, equipped docudrama to respond to challenging circumstances. It could fulfil the capacities of the television medium for both social extension and intimate involvement in a period when its component genres faced significant obstacles in doing so.
\end{abstract}




\author{
Keywords \\ docudrama \\ regulation \\ hybridity \\ drama \\ documentary \\ genre \\ television
}

\title{
Introduction
}

This article sketches out some of the circumstances in British television that have made docudrama a key emergent form. As Derek Paget (1998) has suggested in earlier studies, changes in the economic, institutional, generic and reception contexts of television have made space for docudrama and brought it to a new kind of visibility since about 1990. Docudrama has become an increasingly visible way for television to 'work through' reality processing it and worrying over it in order to define, explain, narrate, render intelligible, marginalize or speculate (Ellis 1999). But rather than claiming that docudrama has attained an identifiably coherent identity as a genre, the argument of this article is that it has mutated into a wide range of forms and formats, with a range of modes of address and aesthetic tone. Docudrama is part of a larger process of negotiation, experiment and competition with related fictional and factual television forms (Bignell 2005), and its identities are the result of both pressures and opportunities. 


\section{The Broadcasting Act of 1990 and its aftermath}

The 1990 Broadcasting Act reduced budgets for television programmes originated by 'BBC' and the commercial 'ITV' companies, because it required them to commission 25 per cent of programme time from independent producers. The same rules applied to 'Channel 4' and the incipient 'Channel 5', though they were already expected to rely on outside commissions rather than in-house production. The effect of the regulations was to increase internal competition between producing departments within the major broadcasters, now competing against outsiders as well as each other, and to place greater emphasis on 'value for money'. The independent production sector expanded massively and quickly, and producers sought new genre hybrids and new formats that they could offer to the main channels. The ecology of television production was being reconfigured, and docudrama could occupy new kinds of niche. But the small independent production companies tended to specialize in a narrow range of genres, especially light factual and entertainment ones because they were generally cheaper to produce than drama or specialist documentary. As the Conservative Government cleared the ground for the regional 'ITV' companies to consolidate into one organization (which finally occurred under a Labour administration in 2003), the large regional production centres responded by playing to their strengths.

For example, the respected current affairs division at the North of England's regional 'ITV' company, Granada, used its expertise to produce some high-profile docudramas including 'Who Bombed Birmingham?' (ITV/HBO, 1990), 'Why Lockerbie?' 
(ITV/HBO, 1990) and 'Hostages' (ITV/HBO, 1993). The first of these was closely based on an investigation carried out for Granada's 'World in Action' (ITV, 1963-1998) current affairs series, about the flawed investigation of IRA bombings in Birmingham, and was watched by ten million viewers. Granada could use audience research evidence to claim that the docudrama transformed the opinions of its audience, from 25 per cent believing before transmission that the six people imprisoned for the bombings were innocent, to 75 per cent believing them innocent after viewing the programme (Fitzwalter 2008: 80-1). ${ }^{2}$ The alleged bombers were subsequently released, but high-profile docudramas like this stimulated right-wing opinion among the elites drafting the 1990 Broadcasting Act, and there were calls for a legally enforceable requirement for 'balance' in broadcasting output. Docudrama was a controversial but effective means for television to perform the role of a public service operating in the public interest, but the version of privatization and competition introduced by the 1990 Act introduced an era of destabilization in the institutions of British television and the relationships between producers, genres and audiences. Referring to Granada's docudrama output around 1990, the company's head of current affairs from 1987-1993, Ray Fitzwalter (2008: 85-6) lamented the reduction in resources for investigative programmes and the pressure on ITV companies to maximize revenue by courting mass audiences.

There were perceived crises in docudrama's component genres in the post-1990 period. Audience sizes and ratings shares fell for current affairs and investigative documentary, a sober tradition of factual programming based on a professional production culture with roots in journalistic documentary. Thames TV's 'This Week' (ITV, 1968-1992) was cancelled in 1992 (Holland 2006), and 'World in Action' in 1998 
(Corner et al. 2007). Factual production departments were competing for fewer slots in the schedule and for commissioning funds. In the 1990s, new technologies of lightweight digital video cameras and high-capacity editing suites coincided with what John Corner (2000) has described as a crisis of confidence in the conventions of television documentary. Digital cameras could produce footage suitable for television, at much higher visual quality than analogue video, using natural light and recording synchronized sound. As the capacity of Avid editing suites increased, it became possible to assemble programmes more easily and quickly. Alongside the drive to make programmes more cheaply by using the new technologies, by 1999 public and press confidence in the veracity of documentary was challenged by a series of controversies about 'faked' footage and manipulation in factual programmes (Ellis 2005). ${ }^{3}$ The emergent television form deriving from both documentary conventions and drama, the docusoap, provided a ready way out of this crisis for television institutions. Docusoaps never aspired to the same sober respect for actuality as conventional documentary, and were less subject to criticism for that reason. The lessening ability of documentary makers to gain access to locations like workplaces, because once there they might cause trouble for the hotels, hospitals or other institutions they featured, meant that conventional documentary was becoming more difficult to make. But for docusoaps where characterization and entertainment were more important than drilling down into the workings of an institution, these problems of access were much less significant.

Factual entertainment in docusoaps became increasingly visible as they moved from the daytime to the evening schedules of the main channels (Corner 2002). Docusoaps like 
'Driving School' (BBC, 1997), originally produced under the aegis of the BBC's Education department, offered new subjects, new relationships with those subjects, a new visual system (both framing and editing), new forms of narrative construction and a novel place in the schedules. It is not surprising, then, that the nature of factual television was suddenly thrown into question, especially as it happened alongside other developments like the enfranchisement of everyday argument and opinionated speech in daytime talk shows. (Ellis 2005: 346)

The series was planned to focus on the driving instructors rather than their pupils, but in the process of making the programme, the pupils were more interesting and the emphasis of the programme changed. 'Driving School' was scheduled against the popular 'ITV' police drama 'The Bill' (ITV, 1984-2010) yet attracted twice as many viewers with a peak audience of 12.5 million. Programme makers accustomed to working in inherited documentary forms had good reasons to shift their activity towards the more easilyproduced, more easily-defended and more audience-pleasing form of the docusoap. For example, Chris Terrill, maker of the 'BBC' docusoap 'The Cruise' (1998) had first made observational documentary such as the BBC series 'HMS Brilliant' (1995), but achieved remarkable success as 'The Cruise' audience rose to a peak of eleven million. ${ }^{4} \mathrm{BBC} 1$ 's first prime time factual programme, 'Airport' (1996-2005), which moved from 'BBC2' to ' $\mathrm{BBCl}$ ' in 1998 , attracted a 44 per cent audience share, and in response 'ITV' moved their competitor, the fire service drama 'London's Burning' (1986-2002) to a different placing in the schedule. In 1998 the 'ITV' docusoap 'Airline' (1998-) achieved a 50 per 
cent average audience share, with 11.4 million viewers, while BBC's 'Animal Hospital' (1994-2004) attracted ten million viewers and a share of 40 per cent.

Reality TV decisively demonstrated the appeal of factual entertainment when the final episode of the first 'Big Brother' (Channel 4, 2000) attracted ten million viewers. Both docusoap and Reality TV shifted the boundaries between ordinariness and celebrity by elevating the ordinary people of workplace docusoaps or the 'Big Brother' contestants into public figures, or by publicly exposing the emotional and psychological foibles of celebrities. The discourse of confession began to compete with discourses of analysis and expertise in factual genres (Dovey 2000: 121-32), and factual television moved towards the tension, conflict and focus on characterization that were conventionally the province of drama. The scripted dramas and situation comedies that had formerly occupied midevening schedule positions were replaced by docusoaps and light factual series (Brunsdon et al. 2001).

In drama, the major broadcasters invested significant budgets in high-profile projects, but the escalation of production cost above inflation led to aversion to risk and strategies to secure continuing audiences by perpetuating strong formats, such as 'Casualty' (BBC, 1986-) or 'Inspector Morse’ (ITV, 1987-2000). As Georgina Born (2004: 172-3) has described with reference to the 'BBC', producers at the major channels competed with each other and outside independent companies to gain the smaller number of commissions, and tended to gravitate to the middle ground of middlebrow programming. Another strategy was reliance on stars, especially at 'ITV', which contracted David Jason, Sarah Lancashire and Robson Green, for instance, in expensive 'golden handcuff' deals. Co-production and the drive to export were by no means new developments, but 
were another factor in reducing scope for innovative or nationally specific drama projects. Similarly, as had been the case for decades, one-off dramas were harder to get commissioned than series because of their lesser export potential and proportionately greater cost per hour. However, high-concept docudrama attracted co-production funding and export sales, especially if US partners could be secured by casting well-known performers or emphasizing the dramatic potential of the script. ${ }^{5}$ For example, 'Why Lockerbie?' was made by Granada in a co-production deal with the US cable channel 'HBO Showcase'. The programme was broadcast on 'ITV', and on 'HBO' under the title 'The Tragedy of Flight 103. D Day 6.6.1944' (2004) was produced by 'BBC', in collaboration with the United States's Discovery Channel, and French and German companies. The BBC's 'Hiroshima' (2005) was screened on 'BBC', in the United States on 'Showtime' and on 'ZDF' in Germany. Georgina Born (2004: 167) reports that at the end of the 1990s, 'BBC' single dramas co-produced with 'HBO' could attract US investment of as much as $£ 1.5$ million, more than three times as much as the average hourly cost of a 'BBC' drama series at that time.

These developments in documentary and drama opened the way for both docudrama and docusoap, each of which offered attractions that addressed many of the problems affecting their component genres. Naturalism in television fiction derives from theatrical antecedents, but also affects the performance of self in documentary (Paget 2002) since the ideology of television naturalism is based on the notion of character as the determinant of action. In docusoap, character differences, expressed through each subject's performance of 'real' identity, offer engagement with distinctive characters. Distinctiveness was at a premium since it was interest in the central characters of 
docusoaps and light-factual series that drove the public discourse about the programmes, rather than, for example, the insight into occupational roles, institutions and hierarchies that the settings brought with them. For example, in playing out the minute details of domestic life within the enclosed space of the house, and especially the kitchen, 'Wife Swap' (Channel 4, 2003-2009) can be argued to perpetuate a naturalistic tradition of family drama that was increasingly displaced by the cinematic forms that television fiction has taken since the 1970s. Helen Piper (2004: 285) suggests that one could hypothesize that the appeal of 'Wife Swap' rests precisely in its radical development of a territory that television drama abandoned along with the studio play, and the subsequent inflation in series budgets. One might speculate that its evident lack of 'onscreen spend' is actually part of its aesthetic appeal, the lack of gloss and 'quality' signifiers implying that something far more rare and raw has been recorded.

Docudrama could assimilate aspects of this success, since the naturalist match between the docudrama text and a pre-existing reality posed the programme as equivalent to a real perception of social space and the people within it.

Docudrama's textual world is already proposed by the factual base as one that is authentic and plausible, so the terrain of identification and shared norms of subjectivity are pre-established to a greater extent than in scripted fictions. However, the increasing presence of factual hybrids on prime time television since 1990 was recognized by broadcasters and academic analysts to be potentially challenging to the veracity of television representation in general. The media academic Annette Hill conducted audience research on this issue, in which she analysed the views of a sample of 8000 
people in the year 2000. It is evidence of the currency and breadth of concern about the veracity of television factual programming that her work was funded by the Economic and Social Research Council, the Independent Television Commission and 'Channel 4'. Hill asked her sample viewers whether they trusted the veracity of factual programmes that included factual reconstruction. Over 70 per cent of the sample distrusted the programmes, thinking that stories were either exaggerated or made up, and 45 per cent of the sample were not sure whether they could tell the difference between a real story being filmed and a recreation specially for a programme (Hill 2002: 328). In the transformed conditions of British television in the 1990s, docudrama and other hybrids such as docusoap suited the dissolution of genre boundaries and inherited institutional structures, but they raised new anxieties.

\section{Opportunities in docudrama: The performance of witnessing}

A wide range of docudramas since 1990 has adopted the form in order to address events in the past, but also events extrapolated from present trends or speculatively predicted. While based on fact, these programmes have coped with the unavailability of some conventional documentary source material by introducing fictionalized witness testimony and acted reconstruction. ${ }^{6}$ Testimony and witness are crucial to docudrama, because interviews with real or fictional subjects, alongside dramatized reconstructions, emphasize moments of crisis or transformation. The aim is to allow the audience to reflect on the forces impacting on individuals, and on how individuals respond to those forces. The question audiences are invited to ask is 'What was it like to be there?' Docudrama makes the necessity of performance into its primary and acknowledged focus 
of interest, within an overarching intention to inform its audience and to make events accessible. The criteria that viewers bring with them centre on questions of authenticity, but the kinds of authenticity at stake depend on modality - the kinds of match or mismatch between the expressive performance techniques used by witnesses or actors and the factual base that legitimates them. In 'Hiroshima', for example, different television forms were combined to tell the story of the atomic bomb raid in 1945, from the perspectives of both the US military and also its Japanese victims. Archive footage was placed alongside acted reconstruction, and witnesses expressed their impressions of the blast verbally while CGI sequences portrayed them visually in the manner of a disaster movie. Verbal testimony from the pilot of the Enola Gay bomber, Paul Tibbetts, was juxtaposed with performance by the actor Ian Shaw playing Tibbetts's younger self. The viewer is able to shift between ways of accessing performance, looking both at the performer and also through him or her to other kinds of representation such as newsreel footage or CGI action sequences representing the nuclear blast (Bignell 2010). While some of the performances are those of actors representing an historical individual, other people seen on the screen are performing 'being themselves' since they are always aware of being filmed for that purpose.

The hijacking of four airliners on September 11, 2001, each of which crashed in the United States with no survivors, gave rise to a substantial group of docudramas that could address the causes and significance of the attacks with greater scope than conventional documentary. ${ }^{7}$ Because none of the hijackers or passengers could bear witness to the events in person, reconstruction and dramatic speculation on the events as they affected those directly involved could be developed with the assistance of expert opinion, 
journalistic investigation and the exploration of the institutional response to the crisis. 'The Hamburg Cell' (Channel 4, 2004) dramatized the lead-up to the destruction of the World Trade Center towers, as did 'The Path to 9/11' (ABC, 2006). The destruction of the World Trade Center and the experience of those inside the building and their rescuers was dramatized in '9/11: The Twin Towers' (BBC/RTL/France 2/Discovery, 2006). One aircraft crashed before reaching its target, and 'The Flight That Fought Back' (Discovery, 2006) extrapolated from black box recordings to dramatize an attempt to regain control of the airliner from its terrorist pilots.

These programmes bore witness to public and political events with more than just national recognition, but 'hidden' recent histories where no cameras had been present were also explored in British tribunal docudramas, which in many cases had already gained public profile by previous stage performances and/or official public enquiries. Programmes of this type included Paul Greengrass's 'The Murder of Stephen Lawrence' (Channel 4, 1999, screened in the United States on 'PBS' in 2002), which used court transcripts to dramatize an inquiry into the racist murder of a black youth; Peter Kosminsky's 'The Government Inspector' (Channel 4, 2005, also screened in France, Germany and Finland), which dramatized the events preceding the apparent suicide of a government scientist searching for Iraq's supposed 'weapons of mass destruction'; and Michael Winterbottom's 'The Road to Guantanamo' (Channel 4, 2006, screened in about fifteen countries worldwide), which combined documentary and dramatic sequences concerning the capture of three British Muslims and their deportation to the illegal US prison camp. Docudrama moved into the territory of investigative documentary concerned with public sphere debates, especially where these concerned high-profile 
events that bore on controversial issues of racism, terrorism and the covert state activity that claimed to combat it, and preparations for war that were supposedly justified by acts of terrorism.

Alongside this strand of docudrama dealing with high-profile political debates, longer-term and more domestic social and political concerns also adopted a docudramatic mode. The five-part 'BBC' docudrama series 'If [...]' (2004-2006) addressed social and economic issues that might, in earlier times, have been the topic of current affairs or documentary programmes. 'If [...] The Lights Go Out' addressed Britain's dependence on imported energy by dramatizing an energy crisis in 2010. 'If [...] Things Don't Get Better' investigated the increasing gap between the wealthy and the relatively poor by imagining social unrest in 2012. 'If [...] The Generations Fall Out' projected the tensions in 2024 between middle-class pensioners and the young adults whose tax burden will need to rise dramatically to fund their elders' retirement. 'If [...] It Was a Woman's World' presented a feminist society of 2020 in which men had become second-class citizens, and 'If [...] We Don't Stop Eating' imagined government policies designed to stigmatize and punish the overweight. These docudramas used conventions drawn from journalism and investigative documentary, such as voice-over information and statistics. A group of fictional characters affected by the consequences of the imagined future were introduced into the scenario, and their personal stories illuminated it, offering relationships of identification to the viewer. The premise of conditional-tense ('hypothetical') docudramas is that 'it could be you', actualizing the ordinary detail of how a future scenario could be experienced. Voice-over and extrapolation from factual data claim one kind of authenticity, while naturalistic performance claims another. 
Conditional-tense docudrama had a more obvious connection with public sphere concerns in its extrapolation of current affairs discourses about terrorism. An actual incident on Tokyo's subway system preceded 'Gas Attack' (Channel 4, 2001), a docudrama that portrayed the sequence of events that might occur following a deliberate release of nerve gas in a British city. Many media outlets had aired speculation that the next likely terrorist threat following $9 / 11$ could be a pandemic started from stolen experimental germ samples, and 'Smallpox 2002: Silent Weapon' (BBC, 2001, 2002) addressed the authorities' poor preparedness for such an attack. Similarly, 'Dirty War' (BBC/HBO, 2004) explained and dramatized the potential impact of the detonation in central London of a small explosive device that contaminated the ground, the air and passers-by with stolen radioactive isotopes. 'The Day Britain Stopped' (BBC, 2003) combined an imagined terrorist attack on London's financial district, a plane crashing on the city and gridlock on London's orbital motorway at Christmastime. The resulting pressures on emergency services and political leadership in the emergency were analysed as institutional problems, in the tradition of documentary investigation, and were personalized by focusing dramatic sequences on individuals affected by the crisis or involved in trying to manage its effects. These programmes integrated scripted drama with archive news footage and other signifiers of actuality, such as CCTV video. They cast little-known actors in reconstructions, simulated news interviews, expert testimony and witness statements. Their understated performance style signified the ordinariness of the fictionalized characters by adopting the psychological naturalism expected from popular television drama (Paget 2007), and the matter-of-fact tone commonly used by professionals and experts in documentary and factual genres such as science programmes. 


\section{The lure of dramatization}

As the 1990s continued, docu-dramatization was used in a greater range of factual programming to enliven other genres associated with 'sobriety' (Nichols 1991) in order to offer the kinds of immersive participation discussed above in historical docudrama, and with a similar offer to answer the question of what it might have been like to witness events that are necessarily inaccessible to television. The true-crime appeal genre epitomized by 'Crimewatch UK' (1984-) had already integrated docudrama in order to reconstruct crimes that had not been audio-visually recorded (paralleling the screening of other crimes recorded by CCTV). The series ‘A History of Britain' (BBC, 2000) presented by Simon Schama used occasional reconstruction, for example of the comings and goings of a Tudor royal court, to enliven accounts of key figures and historical turning points. The subsequent series 'Simon Schama's Power of Art' for 'BBC' (2006) also adopted docudramatic performance to reconstruct historical events and personae such as Vincent Van Gogh creating his paintings of sunflowers. Docudrama enhances the attractions of narrative, character and performance that more conventional types of documentary and factual series have tended to underplay. The factual base invites the viewer to evaluate the programme in relation to the real events, settings and personae represented, and also in relation to the ways the viewer has perceived them in other media representations. Docudramas draw on performance modes from fictional television forms and invite audiences to deploy their knowledge of codes used in fiction. These hybrid frameworks militate against the authenticity or sobriety associated with documentary and the 'personal view' format of earlier arts series like 'Civilisation' (BBC, 1969) or 'The 
Shock of the New' (BBC, 1982), but the multiplicity of interpretive frameworks and routes of access can also broaden the pleasures and social purchase of genres that lack the mainstream audience appeal of popular drama, light entertainment or docusoap.

Conversely, entertainment and drama producers revived established fiction genres by absorbing or appropriating docudramatic conventions to develop new formats such as the 'mock-documentary' (Roscoe and Hight 2001) and 'mock-docusoap' form of 'The Office' (BBC, 2001).

In docudramas in which female public personalities have been represented by actors, melodramatization has added distinctively to their dramatic structuring of the factual base. For example, 'Thatcher: The Final Days' (ITV, 1991) and 'Diana: Her True Story' (NBC, 1993) focus on women characters, emotion and psychology, and on moments of dramatic intensity (Bignell 2000). The dramas were promoted as factual documents of the women's personal struggles, revealing their private lives and their private reactions to public events according to the conventions of the Hollywood biopic (Neale 2000: 60-5). Their documentary base was signalled by opening statements about the accuracy of their content, and by the appearance of journalists and television cameras within the dramas, frequently intruding into and commenting on the actions of the central figures. Action representing their public appearances was counterposed and given significance through psychological and emotional turmoil. As in melodrama, conflict between characters produces emotional drama, and characters also experience conflicts within themselves that are expressed by conflicting emotions and made concrete through physical, bodily behaviour. In 'Thatcher: The Final Days', Thatcher's familiar patterns of speech and gesture are recreated. In 'Diana: Her True Story', the princess's characteristic glance 
from under the fringe of her hair, and her gradual shift from youthful awkwardness to physical self-confidence are used to recall media images of her, and to chart her emotional development. The lead performers are therefore required to adopt strategies of impersonation, and thus draw attention to the fact they are not the real people they represent (Paget 2002), but at the same time their performances alert audiences to the drama's factual base. As well as facilitating some performance motifs that aided viewer recognition of the lead characters, this accretion of previous representations made pitching and promoting docudramas about high-profile figures easier in a competitive commissioning context. Key events like D-Day or elite figures like Tony Blair or Princess Diana function as hooks around which promotion can be organized. Furthermore, these programmes may have relatively small audiences, but they encourage attentive viewing and are perceived as 'quality' television.

In these examples, different discourses of historiography, analysis and commentary are available to different degrees. In the case of 'D Day 6.6.1944', following the story of a group of ordinary soldiers tends to favour a 'history from below' that connects with the current fascination for family history and living museums. By focusing on ordinary infantry soldiers in the Allied invasion of France, the programme necessarily engaged with a working-class experience, drawing on a discourse that has always been associated with British documentary film-making and that associates the authentic with the ordinary. Across the new factual hybrids of the post-1990 period, notions of the ordinary made possible a new visibility for working class subjects but also subjected the working class to a probing, critical and sometimes ridiculing gaze. ${ }^{8}$ As Helen Wood and Beverly Skeggs (2004) have argued, programmes such as 'Wife Swap' normalize a predominantly 
middle-class code of behaviour, morality and self-presentation that frames working-class participants and is adopted as a measure for evaluating their performances for television. The strand of docudrama that is based on and re-enacts the experiences of working-class subjects in the past or in the present has a perhaps surprising connection with the Reality TV game-docs and docusoaps that feature people such as traffic wardens, hotel workers and housewives going about their ordinary business. Like those other emergent factual genres, docudramas based on the testimony of ordinary people occupy a zone of ideological tension. They render an invisible working class visible, but may also scrutinize working-class mores with the effect that class is represented as if it were a matter of conscious lifestyle choices.

'D Day' and other factual and fictional programmes also took advantage of the remaining witnesses who lived through the Second World War and the accounts of lived history they had produced (see Paget and Lipkin 2009). Similarly, BBC produced 'The Trench' (2002) at the point when only a few combatants of the First World War remained and direct witness had to be replaced by re-enactment alongside archival records and photographic evidence. The producers selected 24 contemporary volunteers who would as nearly as possible experience the boredom, squalor and discomfort of an infantry trench at the time of the Battle of Ancre on the Western Front in 1916. Again, ordinariness was a crucial appeal of the three-part series since the volunteers represented rank-and-file soldiers of the 10th Battalion of the East Yorkshire regiment. After three days of military training for the whole group of volunteers, the selection of the final 24 to feature in the series took place. The intention, as with many other programmes using recreation in this way, was to make the historical subject of the First World War 
accessible to young adult audiences (Hanna 2007). Thus the conventions of a Reality show (selection of 'ordinary' contestants, bodily discomfort, physical challenges, a controlled and surveilled space) were adopted to largely replace the more conventional programme material of archive film. The documentation of everyday life in the simulated past was supplemented by interviews with veteran soldiers, and what archive film and photographs were available. While vulnerable to criticism for its populist and nonacademic approach to historiography, 'The Trench' matched the recent shifts in television towards offering understanding through empathy, creating narratives around bodily tests and personal transformation (De Groot 2009: 163-80). Its hybrid modes of address, combining sobriety with entertainment appeal, are evidenced, for example, by the Imperial War Museum exhibition mounted as a spin-off from the programme.

In 'The Deal' (Channel 4, 2003), by contrast, the programme draws more on 'Great Men' discourses of historiography, where decisive moments are personalized around the key players. This one-off film offered a recreation of a meeting between Tony Blair and Gordon Brown at a London restaurant that reputedly took place after the death of Labour Party leader John Smith in 1994. In the film, directed by Stephen Frears, Brown agrees to allow Blair to stand unopposed for the Labour leadership, thus enabling Blair to attain the premiership at the 1997 election. He receives in exchange a promise that Brown would direct domestic policy and would be Blair's assumed successor as Prime Minister. The conventions of documentary film-making involve claims to legitimacy by reference to sources, usually written ones, and expectations of journalistic accuracy, but the nature of the private meeting between the politicians precluded recourse to public records or willing corroboration. ${ }^{9}$ Docudrama avoids some of the problems of sources, especially 
their partial or total inaccessibility, by allowing some speculation about causal relationships and permitting the creation of storylines by telescoping events, condensing characters together or omitting dramatically unnecessary detail. 'The Deal' drew on docudrama's accepted parameters in some of these ways, framing the action with an opening caption that declared somewhat equivocally, 'much of what follows is true'. Dramatization, then, functioned as a means to facilitate the telling of a story that could not meet documentary standards of factual accuracy and also offered the lure of behindthe-scenes access to key political decisions that could be presented as a personal face-toface negotiation between two familiar figures.

The rhetorics of documentary presuppose the inherently 'unnatural' procedures of the recording processes of camera operator and sound recordist, and editing for argument or narrative. The form inhabits a tension between being on the one hand representative and 'accurate', and on the other hand working with conventions of argument or storytelling. In the 1990s techniques such as covert filming, or thematizing the documentary maker's relationship with his or her subject became familiar from the work of Nick Broomfield or Louis Theroux, for example. This reflexive mode in documentary ran alongside docusoap and docudrama, which also in their different ways recognized the structuring and creative work that made the material visible. From an institutional perspective, these kinds of dramatic shaping might also offer the added benefit of enhancing export potential by connecting with the US faction tradition (exemplified by 'Washington Behind Closed Doors', ABC, 1977), in which character and dramatic structure are at least as important as analytical veracity. As the contributors to Alan Rosenthal's collection of essays (1999) and as Steven N. Lipkin's monograph (2002) 
have shown, US factual film-makers have become increasingly occupied in making factbased drama, and thus a transnational anglophone market and institutional structure has developed for the form. Across the television landscape in the 1990s and afterwards, dramatization in docudrama, and also in more conventional documentary and its extension into docusoap was attractive to programme-makers for a range of practical, institutional and aesthetic reasons.

\section{Docudrama as a response to changes in television}

Docudrama exploits the hybrid social functions of television, in which the medium inhabits a tension between being a window onto, and a mirror of, the social worlds it represents and the audiences to whom it is addressed (Gripsrud 1998). In 2003, for example, BBC Producers Guidelines still included the principle that 'The BBC has a responsibility to serve all sections of society in the United Kingdom. Its domestic services should aim to reflect and represent the composition of the nation.' Docusoap, with its inherent drive to investigate character in extended serial formats reminiscent of domestic and workplace drama, exemplified a docu-dramatization of the window and mirror functions that Public Service television was still required to fulfil. As a subset of documentary, docudrama can emphasize immediacy, the screen as a window, and representations of the public world. However, many docudramas are interested in intimacy, character, and a mirroring, comparative relationship between the viewer and the people featured in the programme. Docudrama has worked with the interdependent documentary and dramatic resources offered by the present cultural forms of the television medium. 
Multi-channel television, including genre-specific satellite and digital channels have given greater opportunity for traditional documentary to be screened, though it tends to appear at later times in the evening schedule and on minority channels such as the 'History Channel', 'BBC2' or 'Channel 4'. The prime time slots in the $8.00 \mathrm{pm}$ to 10.00 pm period on terrestrial television are more likely to be filled by docusoaps, gamedocs, Reality TV programmes and of course docudrama. Docudrama has carved out a niche that responds to changes in its component genres and has changed them in its turn. The concept of genre may offer an illusory promise of stability and unity, but genre is also a means for change in programmes and relationships with audiences (Altman 1999). Against a background of rapid change in the particular moment of the last two decades, docudrama has further exploited the formal hybridity and flexibility of address that define it. Growing in significance since 1990 for the reasons I have outlined, docudrama in Britain has not simply displaced documentary or drama but has been an appropriate response to a changing ecology in television.

\section{Acknowledgements}

This article is one of the results of the research project 'Acting with Facts: Performing the Real in British Theatre and Television Docudrama since 1990' funded by the Arts \& Humanities Research Council. The research was led by Derek Paget at the University of Reading from 2007-2010, working with Jonathan Bignell, Lib Taylor and the project's postdoctoral fellow Heather Sutherland.

\section{References}


Altman, R. (1999), Film/Genre, London: BFI.

BBC (2003), Producers Guidelines, London: BBC.

Bignell, J. (2000), 'Docudrama as Melodrama: Representing Princess Diana and Margaret Thatcher', in B. Carson and M. Llewellyn-Jones (eds), Frames and Fictions on Television: The Politics of Identity within Drama, Exeter: Intellect, pp. 17-26. (2005), Big Brother: Reality TV in the Twenty-first Century, London: Palgrave Macmillan. (2010), 'Docudrama Performance: Realism, Recognition and Representation', in C.

Cornea (ed.), Genre and Performance: Film and Television, Manchester: Manchester University Press.

Born, G. (2004), Uncertain Vision: Birt, Dyke and the Reinvention of the BBC, London: Secker \& Warburg.

Brunsdon, C., Johnson, C., Moseley, R. and Wheatley, H. (2001), 'Factual entertainment on British television: the Midlands TV Research Group's 8-9 project', European Journal of Cultural Studies, 4:1, pp. 29-62.

Bruzzi, S. (2006), New Documentary, 2nd ed., London: Routledge.

Corner, J. (2000), 'What can we say about documentary?', Media, Culture and Society 22:5, pp. 681-8. (2002), 'Performing the real: documentary diversions', Television and New Media, 3:3, pp. 255-69.

Corner, J., Goddard, P. and Richardson, K. (2007), Public Issue Television: World in Action 1963-98, Manchester: Manchester University Press. 
De Groot, J. (2009), Consuming History: Historians and Heritage in Contemporary

Popular Culture, London: Routledge.

Dovey, J. (2000), Freakshow: First Person Media and Factual Television, London:

Pluto.

Ellis, J. (1999), ‘Television as Working through', in J. Gripsrud (ed.), Television and Common Knowledge, London: Routledge, pp. 55-7.

(2005), 'Documentary and Truth on Television: the Crisis of 1999', in A. Rosenthal and J. Corner (eds), New Challenges for Documentary, 2nd ed., Manchester: Manchester University Press, pp. 342-60.

Fitzwalter, R. (2008), The Dream that Died: The Rise and Fall of ITV, Leicester:

Matador.

Gripsrud, J. (1998), 'Television, Broadcasting, Flow: Key Metaphors in TV theory', in C. Geraghty and D. Lusted (eds), The Television Studies Book, London: Arnold, pp. 17-32. Hanna, E. (2007), 'Reality-experiential history documentaries: The Trench (BBC, 2002) and Britain's modern memory of the First World War', Historical Journal of Film, Radio and Television, 27:4, pp. 531-48.

Hill, A. (2002), 'Big Brother: the real audience', Television and New Media, 3:3, pp. 323-41.

Holland, P. (2006), The Angry Buzz: This Week and Current Affairs Television, London: I. B. Tauris.

Kilborn, R. (1994), “"Drama over Lockerbie”: a new look at television dramadocumentaries', Historical Journal of Film, Radio and Television, 14:1, pp. 59-76. 
(2003), Staging the Real: Factual TV Programming in the Age of Big Brother,

Basingstoke: Palgrave Macmillan.

Lipkin, S. (2002), Real Emotional Logic: Film and Television Docudrama as Persuasive

Practice, Carbondale, IL: Southern Illinois University Press.

Neale, S. (2000), Genre and Hollywood, London: Routledge.

Nichols, B. (1991), Representing Reality: Issues and Concepts in Documentary,

Bloomington: Indiana University Press.

Nimmo, D. and Combs, J. ([1989] 1993), Mediated Political Realities, New York:

Longman.

Paget, D. (1990), True Stories?: Documentary Drama on Radio, Stage and Screen, Manchester: Manchester University Press. (1998), No Other Way to Tell It: Dramadoc/Docudrama on Television, Manchester: Manchester University Press. (2002), 'Acting a part: performing docudrama', Media International Australia, 104, pp. $30-41$. (2007), “"Acting with facts": actors performing the real in British theatre and television since 1990. A preliminary report on a new research project', Studies in Documentary Film, 1:2, pp. 165-76.

Paget, D. and Lipkin, S. (2009), “"Movie-of-the-Week” docudrama, "historical-event” television, and the Steven Spielberg series Band of Brothers', New Review of Film and Television Studies, 7:1, pp. 93-107.

Piper, H. (2004), 'Reality TV, Wife Swap and the drama of banality', Screen, 54:4, pp. $273-86$. 
Roscoe, J. and Hight, C. (2001), Faking It: Mock-documentary and the Subversion of Factuality, Manchester: Manchester University Press.

Rosenthal, A. (ed.) (1999), Why Docudrama?: Fact-Fiction on Film and TV, Carbondale, IL: Southern Illinois University Press.

Winston, B. (1988), 'The Tradition of the Victim in Griersonian Documentary', in A. Rosenthal (ed.), New Challenges for Documentary, Berkeley: University of California Press, pp. 269-80. (2000), Lies, Damn Lies and Documentaries, London: BFI.

Wood, H. and Skeggs, B. (2004), 'Notes on ethical scenarios of self on British Reality TV’, Feminist Media Studies, 4:2, pp. 205-8.

\section{Contributor details:}

Jonathan Bignell is Professor of Television and Film at the University of Reading and Co-Investigator on the 'Acting with Facts' project. His books include Beckett on Screen, Postmodern Media Culture and Big Brother: Reality TV in the Twenty-first Century, and the edited collections A European Television History, Writing and Cinema, Popular Television Drama: Critical Perspectives and British Television Drama: Past, Present and Future. He serves on the editorial boards of the journals New Review of Film and Television Studies, Symbolism: An International Annual of Critical Aesthetics and the Journal of Science Fiction Film and Television.

\section{Contact:}


Department of Film, Theatre \& Television, Bulmershe Court, University of Reading, Reading RG6 1HY, UK.

e-mail: j.bignell@reading.ac.uk

\footnotetext{
${ }^{1}$ Key studies addressing docudrama include Lipkin (2002), Paget $(1990,1998)$ and Rosenthal (1999).

${ }^{2}$ The audience research evidence referred to by Fitzwalter must be seen in the context of his defence of Granada's current affairs output. For an analysis of audience relationships with docudrama, which includes more sceptical responses, see Kilborn (1994).

${ }^{3}$ On debates around faking in documentary, see Bruzzi (2006), Ellis (2005), Kilborn (2003) and Winston (2000).

${ }^{4}$ See Bruzzi (2006: 120-52) for a discussion of Terrill's work in the context of changes in observational documentary and Reality TV.

${ }^{5}$ For a detailed study of the commissioning, development and production process of the Granada co-production of 'Hostages' (1992) with 'HBO', for example, see Paget (1998: 170-94).

${ }^{6}$ The Thin Blue Line (Errol Morris, 1988) is a fundamental reference point for the use of witness testimony alongside re-enacted sequences. The film presents and analyses different accounts of the murder of a police officer in Texas in 1976.

${ }^{7}$ See Nimmo and Combs ([1989] 1993) for the argument that docu-dramatization is one among many media strategies to rapidly shape the significance of political events, with the effect of transforming the reality they represent.

${ }^{8}$ The documentary film-maker Paul Watson observed the life of a working class family in 'The Family' (BBC, 1974) and received a BAFTA award for his achievements in 2008. In his acceptance speech he condemned contemporary factual formats including docusoap, talent shows and 'Big Brother' for their contemptuous ridiculing of the ordinary people appearing in them.

${ }^{9}$ See Winston (1988) for a wide-ranging analysis of the relationships between filmmakers and documentary subjects, including questions of access and empowerment.
} 